\title{
Inovasi Pembelajaran Daring dan Dampak Bagi PAUD Selama Pandemi Covid-19
}

Muh. Yusri Bachtiar ${ }^{1}$, Nasrullah $^{2}{ }^{\bowtie}$

Pendidikan Guru Pendidikan Anak Usia Dini, Universitas Negeri Makassar, Indonesia( ${ }^{(1)}$

Pendidikan Matematika, Universitas Negeri Makassar, Indonesia( ${ }^{(2)}$

DOI: 10.31004/obsesi.v6i2.1411

\begin{abstract}
Abstrak
Pentingnya penelitian ini untuk menelusuri seperti apa inovasi pembelajaran daring yang dikembangkan dan dampak yang ditimbulkan bagi PAUD selama masa pandemi Covid-19. Jenis penelitian yang digunakan adalah kuantitatif-deskriptif dimana instrumen yang digunakan berupa kuesioner dengan media sebar berbasis platform google form. Responden yang terlibat sebanyak 369 orang di Sulawesi Selatan. Hasil penelitian menunjukkan bahwa IPD yang dibuat berkembang dalam bentuk 30 variasi APD dan 4 variasi pembelajaran hybrid. Praktik baik ini berdampak pada penggunaan APD dalam hal pemanfaatan dan adaptasi. Meskipun tidak semuanya berpengalaman, pengalaman menjadi pengetahuan awal bagi pengguna tentang APD sedemikian sehingga berdampak pada kemudahan penggunaan. Tanpa pengalaman tidak berarti menjadi kendala bagi mereka merasakan manfaat APD tersebut. Dari proses pemanfaatan dan adaptasi APD, responden cenderung tidak mengutamakan APD mendukung tumbuh kembang peserta didik baik kognitif, sikap, maupun psikomotorik. Namun, responden cenderung mendukung APD dapat membantu peserta didik untuk meningkatkan kemampuan kognitif, perkembangan sikap, dan perkembangan psikomotorik.

Kata Kunci: inovasi; daring; anak usia dini
\end{abstract}

\begin{abstract}
The importance of this research is to explore what online learning innovations have developed and the impact they have on ECEP during the Covid-19 pandemic. The type of research used is quantitative-descriptive where the instrument used is a questionnaire with spread media based on the google form platform. The respondents involved were 369 people in the South Sulawesi region. The results showed that the OLI made developed in the form of 30 variations of OLA and 4 variations of hybrid learning. These good practices have an impact on the use of OLA in terms of utilization and adaptation. Although not all have experience of use, at least experience is initial knowledge for users about OLA in such a way that it has an impact on ease of use. Without experience, it does not mean that they are an obstacle for them to feel the benefits of using the OLA. From the process of utilizing and adapting OLA, respondents tend not to prioritize OLA to support the growth and development of students, both cognitive, attitude, and psychomotor. However, respondents tend to support that OLA can help students to improve cognitive abilities, attitude development, and psychomotor development.
\end{abstract}

Keywords: inovation; online; early childhood

Copyright (c) 2021 Muh. Yusri Bachtiar, Nasrullah

$\triangle$ Corresponding author:

Email Address : nasrullah@unm.ac.id @unm.ac.id (alamat koresponden)

Received 31 january 2021, Accepted 28 June 2021, Published 31 July 2021 


\section{PENDAHULUAN}

Adanya pandemi covid-19 ternyata memberikan pelajaran berharga bagi dunia pendidikan anak usia dini di Indonesia. Kita ketahui Bersama bahwa metode pembelajaran tatap muka secara daring masih diperdebatkan perlu atau tidak diterapkan. Namun, kegiatan pembelajaran secara daring pun dilaksanakan dengan menyesuaikan situasi dan kondisi yang terjadi saat ini. Tidak semua guru dan siswa akan mengira bahwa mereka harus bertemu secara tatap maya. Aktivitas tatap maya pun memberikan banyak pengalaman belajar baru, terutama guru dan orang tua. Keduanya menunjukkan bagaimana mereka berperan sebagai mitra kerja dalam pendidikan anak. Menurut Dong et al. (2020), orang tua anak usia dini di Cina berpendapat bahwa anak-anak mereka menghabiskan waktu kurang dari setengah jam setiap kali pembelajaran online di gelar selama pandemi Covid-19. Mereka cenderung menganggap bahwa pembelajaran online tidak tepat bagi anak-anak mereka sehingga berpikir bahwa pembelajaran tradisional masih menjadi pilihan utama.

Tentunya pendapat ini tidak bisa digeneralisasi begitu saja. Untuk konteks Indonesia, aktivitas pembelajaran daring seakan menjadi kewajiban karena guru dan anak usia dini tidak terbiasa mengikuti kegiatan pembelajaran yang dilaksanakan dengan perantara perangkat elektronik. Secara tidak langsung, kewajiban ini berasal dari Pemerintah yang melalui kebijakan pembatasan pembelajaran tatap muka selama masa pandemi Covid-19. Bahkan pemerintah menyiapkan aplikasi pembelajaran jarak jauh berbasis android, yang disebut "Portal Rumah Belajar" (Abidah et al., 2020; Kemdikbud, 2020). Ini menarik, meskipun masih diperdebatkan bahwa apakah anak usia dini sudah layak mengikuti kegiatan pembelajaran secara online. Padahal Aubrey \& Dahl (2014) menganggap bahwa anak usia dini sudah layak mendapat pemahaman tentang peralatan teknologi dan digital, tentunya diiringi dengan praktik sosial dan budaya yang berlangsung di rumah.

Meskipun demikian, ini merupakan tantangan bagi guru dalam kegiatan pengajaran mengenai tindakan kelas yang diberikan kepada siswa tingkat usia dini. Sistem pembelajaran daring untuk level taman kanak-kanak masih tergolong baru di Indonesia (Wulandari \& Purwanta, 2020) sehingga pengajaran anak usia dini di masa pandemi memberikan tantangan khusus bagi guru yang subjek pengajarannya adalah anak usia dini. Phajane (2014) berpendapat bahwa pendidik anak usia dini memiliki pekerjaan yang memiliki 2 tujuan yaitu mempersiapkan anak dalam rentang usianya hal yang berkaitan secara akademik, sosial, emosional, dan fisik. Selain itu, fokus yang kedua dari pekerjaan mereka adalah melindungi dan merawat anak dari kekosongan pemberi perhatian utama kepada anak (Fenech, 2007). Kerjasama dan koordinasi yang baik antara guru dan orang tua sangat dibutuhkan dalam hal ini.

Seperti yang diketahui bahwa Indonesia merupakan negara kepulauan, tidak mudah melaksanakan pembelajaran daring karena kendala kondisi geografis dan ketersediaan fasilitas untuk itu. Untuk wilayah Sulawesi Selatan, pendidikan melalui media berbasis online memberikan kesempatan peserta didik berkembang secara mandiri berdasarkan pola pembinaan para pendidik (Ammas, 2021). Akan tetapi, gambaran terbaru bahwa dengan sistem pembelajaran daring menyebabkan sebagian besar pencapaian perkembangan anak mengalami penurunan (Wulandari \& Purwanta, 2020). Selain itu, penguasaan aplikasi menjadi masalah besar untuk pembelajaran yang dilaksanakan bagi peserta didik usia dini (Harahap et al., 2021)

Padahal pemanfaatan perangkat pembelajaran daring dapat meningkatkan kelekatan hubungan dengan anaknya dan orang tua dapat melihat langsung perkembangan kemampuan anaknya dalam belajar (Cahyati \& Kusumah, 2020; Susanti \& Prameswari, 2020). Di kalangan perguruan tinggi, pembelajaran daring menjadi modus baru yang menginisiasi semangat pembelajaran di era normal baru (Ratu et al., 2020). Salah satu kontribusi positif dari pembelajaran secara daring ini dapat mendukung perubahan positif terhadap kemampuan penalaran dan komunikasi (Nasrullah; Baharman, 2016). 
Beberapa studi yang berkaitan dengan pemanfaatan perangkat pembelajaran daring ditunjukkan dalam bentuk sebagai media untuk memfasilitasi pendidik dan menyampaikan materi pembelajaran, penyelenggaraan literasi, dan pelatihan (Hanifah Salsabila et al., 2020). Atau, menyiapkan berbagai aktivitas yang berfungsi sebagai ajang bagi siswa untuk menyelesaikan berbagai masalah yang pada gilirannya dapat meningkatkan kemampuan menyelesaikan masalah (Ridwan \& Nasrullah, 2015). Perangkat yang mendukung pembelajaran terpusat \& melatih kemandirian (Ammas, 2021), waktu dan lokasi yang fleksibel, biaya yang terjangkau untuk para peserta, akses yang tidak terbatas dalam perkembangan pengetahuan (Andrianto Pangondian et al., 2019). Diiringi dengan proses adaptasi dimana komitmen tidak hanya guru dan orangtua, termasuk siswa. Pembelajaran daring dapat menjadi ruang bagi orang tua, sarana pembelajaran dan kreativitas guru, serta mendorong motivasi siswa menjadi bagian yang perlu ditumbuhkan dan diarahkan menjadi disiplin (Fadlilah, 2020). Adaptasi guru yang dimaksudkan dalam pembelajaran daring dengan menggali informasi untuk menambah pengetahuan dan memperluas pengalaman belajar sehingga motivasi mereka dalam menjaga komitmen melaksanakan pembelajaran daring perlu terus dipertahankan (Lindawati, 2019).

Dari tinjauan yang dikemukakan di atas, studi ini akan memberikan informasi berkaitan dengan seperti apa Inovasi Pembelajaran Daring (IPD) yang digunakan oleh guru PAUD di Sulawesi Selatan dan dampak pemanfaatan dan adaptasi Aplikasi Pembelajaran Daring (APD) yang digunakan. IPD dalam studi ini berkaitan dengan pengembangan ide, gagasan, atau strategi pendidik dalam mengolah dan memanfaatkan jenis APD untuk mendukung kegiatan pembelajaran di kelasnya (Jooston et al., 2020). Adapun APD yang dimaksud dalam penelitian ini adalah media pembelajaran tengah berkembang saat ini dan dimanfaatkan oleh pendidik dan peserta didik untuk melaksanakan kegiatan belajar dan mengajar. APD tersebut merupakan media pembelajaran daring yang direkomendasikan oleh pemerintah (Kemdikbud RI, 2020), diantaranya perangkat yang dapat diakses pada laman bersamahadapikorona.kemdikbud.go.id/category/aplikasi pembelajaran, atau aplikasi media sosial yang cukup populer digunakan oleh guru dan orang tua. Beberapa perangkat yang berhasil diidentifikasi, yaitu WhatsApp, Google Classroom, Schoology, Edmodo, Rumah Belajar, Ruang Guru, Quipper School, Meja Kita, Icando, IndonesiaX, Google for Education, Kelas Pintar, Microsoft Office 365, Sekolahmu, Zenius, Cisco Webex, Kipin School, Facebook, Youtube, Twitter, Telegram, dan lainnya (Nasrullah; Baharman, 2017; Enriquez, 2014; Gheytasi et al., 2015; So, 2016; Susanti \& Prameswari, 2020; Suhendro, 2020). Sedangkan dampak pemanfaatan dan adaptasi dikaitkan dengan kegiatan selama pembelajaran daring, misalnya dampak positif pada aspek kognitif dan aspek sosial emosional, juga bahasa (Wulandari \& Purwanta, 2020). Pentingnya dampak pembelajaran daring juga meninjau tumbuh kembang dan kemampuan serta perkembangan peserta didik dalam hal kognitif, afektif, dan psikomotorik (Suhendro, 2020).

Dari tinjauan tersebut, artikel ini mengkaji dua masalah penelitian yang diajukan yaitu, pertama, seperti apa inovasi pembelajaran yang dilakukan tenaga pendidik tingkat usia dini di wilayah Sulawesi Selatan selama masa pandemi Covid-19? Kemudian, apa dampak yang ditimbulkan dari pemanfaatan dan adaptasi aplikasi pembelajaran daring dari segi aspek kognitif, afektif, dan psikomotorik? Kedua rumusan ini diarahkan untuk mempertegas seperti apa inovasi pembelajaran yang diterapkan oleh guru PAUD di Sulawesi Selatan. Pemanfaatan inovasi tersebut tentunya akan memberikan informasi seperti apa penguasaan aplikasi para pendidik. Harapannya mereka mampu meninjau dampaknya sehingga tidak hanya berguna bagi diri mereka sendiri, tetapi juga menjadi bahan kajian bagi para pendidik yang mencoba mengembangkannya dalam kegiatan pembelajaran mereka, terutama untuk anak usia dini.

\section{METODOLOGI}

Penelitian ini dilaksanakan dengan rancangan penelitian kuantitatif dan pendekatan deskriptif. Untuk mendukung pelaksanaan penelitian ini, populasi yang dilibatkan sebagai 
sumber data adalah guru PAUD di Sulawesi Selatan. Adapun jumlah sampel yang berhasil dijaring sebanyak 369 orang.

Dalam mengumpulkan pendapat mereka, instrumen dikembangkan dan disebar menggunakan platform google form. Pengembangan instrumen mengacu pada petunjuk penggunaan platform google form sebagai instrumen survei (Mondal et al., 2019). Untuk penyebaran instrumen, kegiatan ini dimulai 14 April 2021 kepada guru PAUD yang tersebar pada daerah penelitian yang ditargetkan. Terlebih dahulu tim peneliti telah berkomunikasi kepada para responden untuk menyampaikan tujuan penelitian dan sekaligus meminta izin berbagi informasi sesuai petunjuk instrumen penelitian. Agar dukungan pendapat responden tersampaikan dengan baik, mereka diminta untuk membaca dengan baik setiap pernyataan yang diberikan dan dapat mempertanyakan jika ada yang kurang dipahami melalui media yang disepakati.

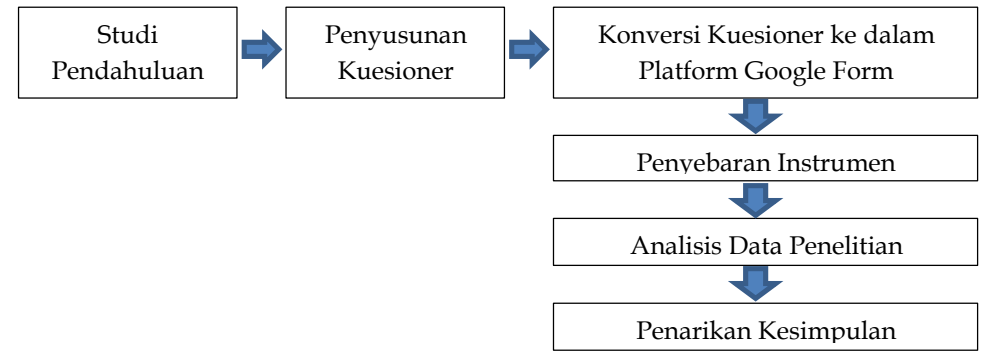

Gambar 1. Alur Penelitian

Instrumen penelitian yang digunakan dalam bentuk kuesioner yang terbagi menjadi 2 aspek yaitu, pemanfaatan perangkat dan respon adaptasi Pembelajaran daring. Perangkat yang dimaksud dalam aspek pertama adalah APD yang direkomendasikan oleh pemerintah dan yang telah diterapkan oleh para pendidik di kelasnya. Kegiatan pembelajaran yang mendukung aktivitas pembelajaran dengan penggunaan APD atau kombinasi beberapa APD disebut dengan variasi. Penelitian ini akan mengungkap variasi-variasi APD yang digunakan oleh para pendidik dimana jenis variasi akan terindeks berdasarkan banyak APD yang digunakan. Misalnya untuk jumlah APD yang digunakan hanya 1 disebut variasi 1 , kemudian jika menggunakan 2 APD berarti variasi 2, dan seterusnya. Pada aspek yang kedua, yaitu respon adaptasi pembelajaran daring ditandai dengan 9 indikator seperti yang ditunjukkan pada tabel 1. Implementasi APD tersebut dikaitkan dengan prinsip tumbuh kembang anak usia dini, dan kemampuan serta perkembangan peserta didik yang dicanangkan juga oleh Kemendikbud. Komponen instrumen yang digunakan dalam penelitian ini ditunjukkan ke dalam tabel 1.

Tabel 1. Komponen Instrumen Penelitian

\begin{tabular}{lll}
\hline No. & \multicolumn{1}{c}{ Aspek } & \multicolumn{1}{c}{ Indikator } \\
\hline 1. & Pemanfaatan perangkat & Variasi 1, Variasi 2,.., dan seterusnya. \\
& Respon adaptasi pembelajaran daring & a. Pengalaman \\
& b. Kemudahan Penggunaan \\
& c. Manfaat Penggunaan \\
& d. APD Dukung Tumbuh Kembang Kognitif \\
& e. APD Dukung Tumbuh Kembang Sikap \\
& f. APD Dukung Tumbuh Kembang Psikomotorik \\
& g. APD dukung Kemampuan Kognitif \\
& h. APD dukung Perkembangan Sikap \\
& i. APD dukung Perkembangan Psikomotorik \\
\hline
\end{tabular}


Seluruh tanggapan yang diperoleh dari responden disimpan secara digital dengan perangkat bantuan berupa google spreadsheet. Sebelum data yang diperoleh dikonversi menjadi data berbasis Microsoft excel dan dianalisis sesuai kebutuhan penelitian. Untuk lebih jelas, Adapun alur langkah-langkah penelitian yang dilakukan diuraikan pada gambar 1 .

\section{HASIL DAN PEMBAHASAN}

Sesuai dengan yang dikemukakan dalam penjelasan di atas, penelitian ini menguraikan seperti apa inovasi pembelajaran yang dilakukan tenaga pendidik tingkat usia dini di wilayah Sulawesi Selatan. Di samping itu, responden penelitian ini diharapkan berpendapat mengenai dampak dari inovasi pembelajaran daring yang dilakukan terhadap peserta didik dalam hal pemanfaatan, adaptasi, dan komitmen. Untuk menguraikan hal tersebut, perhatikan hasil analisis sebagai berikut

\section{Inovasi Pembelajaran Daring Pendidik PAUD Di Sulawesi Selatan}

Inovasi pembelajaran daring atau IPD yang dimaksudkan dalam penelitian ini adalah pengembangan ide, gagasan, atau strategi pendidik dalam mengolah dan memanfaatkan jenis Aplikasi Pembelajaran Daring (APD) untuk mendukung kegiatan pembelajaran di kelasnya. Setiap jenis APD memiliki fungsi dan tujuan masing-masing dimana guru akan melakukan adaptasi dan akomodasi bagaimana menggunakannya. Agar efektif dan efisien, serangkaian ide, gagasan, dan strategi disiapkan untuk melakukan adaptasi dan akomodasi dalam kegiatan pembelajaran. Berdasarkan hasil pengumpulan data, informasi yang diperoleh dari para responden dikemukakan ke dalam tabel 2.

Dari tabel 2 yang ditunjukkan di atas, para pendidik PAUD yang ada di Sulawesi Selatan menerapkan 37 kombinasi strategi untuk mendukung kegiatan pembelajaran. Seperti yang dapat dilihat dalam tabel tersebut dimana 30 kombinasi strategi yang melibatkan aplikasi pembelajaran virtual, dan 4 kombinasi strategi yang memadukan aplikasi pembelajaran daring terpadu kegiatan pembelajaran secara luring. Selain itu, terdapat 3 strategi yang dilaksanakan secara luring, diantaranya kunjungan ke rumah siswa dan luring, lainnya dilaksanakan dengan memadukan antara luring dan guling.

Di dalam 30 kombinasi strategi yang menggunakan APD, terdapat 6 variasi penggunaan APD dalam kegiatan pembelajaran yang dilaksanakan. Dari 6 variasi tersebut, terdapat variasi yang hanya menggunakan 1 APD, yang memadukan 2 APD dan 3 APD. Kemudian yang memadukan 4, 5, dan 6 APD.

Untuk variasi pertama adalah pendidik yang hanya menggunakan 1 APD. Dari respon mereka ternyata penggunaan WA mendominasi dalam mendukung aktivitas pembelajaran daring dimana terdapat 246 orang responden. Selain yang hanya menggunakan aplikasi WA, juga terdapat responden yang memanfaatkan Google for Education, Rumah Belajar, dan Sekolahmu. Hal ini memberikan gambaran bahwa pembelajaran dengan WA tidak menjadi satu-satuya inovasi pembelajaran selama pandemic covid-19.

Selanjutnya, variasi kedua merupakan kombinasi yang menerapkan 2 jenis APD dalam pelaksanaan kegiatan pembelajaran daring. Untuk variasi ini, terdapat 10 kombinasi APD diantaranya 1) Google Classroom, Rumah Belajar, 2) Rumah Belajar, Sekolahmu, 3) Whatsapp, Facebook, 4) Whatsapp, Google Classroom, 5) Whatsapp, Google form, 6) Whatsapp, Icando, 7) Whatsapp, Rumah Belajar, 8) Whatsapp, Sekolahmu, 9) Whatsapp, Youtube, dan 10) Whatsapp, Zoom. Berdasarkan pengguna, kombinasi Whatsapp dan Rumah Belajar, dan kombinasi Whatsapp dan Youtube digunakan lebih banyak dibandingkan kombinasi yang lain, sebanyak 20 orang. Kemudian diikuti pengguna yang mengkombinasikan antara Whatsapp dan Facebook, dan Whatsapp dan Google Classroom sebanyak 6 orang. Terlihat juga ada 2 pengguna yang menerapkan 2 APD sekaligus dalam aktivitas pembelajarannya seperti mengkombinasikan Whatsapp dan Sekolahmu, dan Whatsapp dan Zoom. Selebihnya tercatat hanya dikembangkan oleh 1 pengguna saja. 
Inovasi Pembelajaran Daring dan Dampak Bagi PAUD Selama Pandemi Covid-19

DOI: $10.31004 /$ obsesi.v6i2.1411

Tabel 2. Variasi Aplikasi Pembelajaran Daring (APD) dan Luring yang digunakan guru PAUD

\begin{tabular}{|c|c|c|c|c|c|}
\hline Jenis App yang digunakan & $\begin{array}{l}\text { Paket } \\
\text { App }\end{array}$ & Pengguna & Variasi & Jenis & Jenis \\
\hline Google for Education & P4 & 2 & 1 & 1 & Daring \\
\hline Rumah Belajar & P5 & 10 & 1 & 1 & Daring \\
\hline Sekolahmu & P7 & 1 & 1 & 1 & Daring \\
\hline Whatsapp & P8 & 246 & 1 & 1 & Daring \\
\hline Google Classroom, Rumah Belajar & P2 & 1 & 2 & 1 & Daring \\
\hline Rumah Belajar, Sekolahmu & P6 & 1 & 2 & 1 & Daring \\
\hline Whatsapp, Facebook & P9 & 6 & 2 & 1 & Daring \\
\hline Whatsapp, Google Classroom & P11 & 6 & 2 & 1 & Daring \\
\hline Whatsapp, Google form & P19 & 1 & 2 & 1 & Daring \\
\hline Whatsapp, Icando & P20 & 1 & 2 & 1 & Daring \\
\hline Whatsapp, Rumah Belajar & P21 & 20 & 2 & 1 & Daring \\
\hline Whatsapp, Sekolahmu & $\mathrm{P} 24$ & 2 & 2 & 1 & Daring \\
\hline Whatsapp, Youtube & P27 & 20 & 2 & 1 & Daring \\
\hline Whatsapp, Zoom & P30 & 2 & 2 & 1 & Daring \\
\hline Google Classroom, Edmodo, Cisco Webex & P1 & 2 & 3 & 1 & Daring \\
\hline Whatsapp, Facebook, Youtube & P10 & 4 & 3 & 1 & Daring \\
\hline Whatsapp, Google Classroom, Rumah & & & & & \\
\hline Belajar & P15 & 1 & 3 & 1 & Daring \\
\hline Whatsapp, Google Classroom, Telegram & P16 & 1 & 3 & 1 & Daring \\
\hline Whatsapp, Google Classroom, Youtube & P17 & 5 & 3 & 1 & Daring \\
\hline Whatsapp, Rumah Belajar, Sekolahmu & $\mathrm{P} 22$ & 1 & 3 & 1 & Daring \\
\hline Whatsapp, Rumah Belajar, Youtube & $\mathrm{P} 23$ & 1 & 3 & 1 & Daring \\
\hline Whatsapp, Sekolahmu, Facebook & P25 & 1 & 3 & 1 & Daring \\
\hline Whatsapp, Sekolahmu, Youtube & P26 & 1 & 3 & 1 & Daring \\
\hline Whatsapp, Youtube, Telegram & P29 & 1 & 3 & 1 & Daring \\
\hline $\begin{array}{l}\text { Google Classroom, Youtube, Zoom cloud, } \\
\text { quizizz }\end{array}$ & P3 & 1 & 4 & 1 & Daring \\
\hline Whatsapp, Youtube, Gmeet dan zoom & P28 & 1 & 4 & 1 & Daring \\
\hline $\begin{array}{l}\text { Whatsapp, Google Classroom, Cisco Webex, } \\
\text { Youtube, Telegram } \\
\text { Whatsapp, Google Classroom, Google for }\end{array}$ & P12 & 1 & 5 & 1 & Daring \\
\hline Education, Cisco Webex, Youtube & P14 & 1 & 5 & 1 & Daring \\
\hline $\begin{array}{l}\text { Whatsapp, Google Classroom, Zenius, } \\
\text { Youtube, Telegram }\end{array}$ & P18 & 1 & 5 & 1 & Daring \\
\hline $\begin{array}{l}\text { Whatsapp, Google Classroom, Facebook, } \\
\text { Youtube, Google meet dan zoom }\end{array}$ & P13 & 1 & 6 & 1 & $\begin{array}{l}\text { Daring } \\
\text { Daring } \\
\quad \&\end{array}$ \\
\hline Whatsapp, Berkunjung kerumah siswa & P31 & 1 & 2 & 2 & $\begin{array}{l}\text { Luring } \\
\text { Daring } \\
\quad \&\end{array}$ \\
\hline Whatsapp, Kunjungan rumah & P32 & 1 & 2 & 2 & $\begin{array}{l}\text { Luring } \\
\text { Daring } \\
\quad \&\end{array}$ \\
\hline Whatsapp, Luring & P33 & 1 & 2 & 2 & $\begin{array}{l}\text { Luring } \\
\text { Daring } \\
\quad \&\end{array}$ \\
\hline Whatsapp, Luring Dan guling & P34 & 1 & 2 & 2 & Luring \\
\hline Kunjungan kerumah siswa & P35 & 1 & 1 & 3 & Luring \\
\hline Luring & P36 & 3 & 1 & 3 & Luring \\
\hline Luring dan guling & P37 & 1 & 1 & 3 & Luring \\
\hline
\end{tabular}

1012 | Jurnal Obsesi : Jurnal Pendidikan Anak Usia Dini, 6(2), 2022 
Untuk variasi ketiga berarti pengguna APD mampu mengkombinasikan 3 jenis APD sekaligus dalam berbagai kegiatan pembelajaran mereka. Seperti yang dikemukakan dalam tabel 2, kombinasi tersebut diantaranya, 1) Google Classroom, Edmodo, Cisco Webex, 2) Whatsapp, Facebook, Youtube, 3) Whatsapp, Google Classroom, Rumah Belajar, 4) Whatsapp, Google Classroom, Telegram, 5) Whatsapp, Google Classroom, Youtube, 6) Whatsapp, Rumah Belajar, Sekolahmu, 7) Whatsapp, Rumah Belajar, Youtube, 8) Whatsapp, Sekolahmu, Facebook, 9) Whatsapp, Sekolahmu, Youtube, dan 10) Whatsapp, Youtube, Telegram. Di dalam variasi yang ketiga ini, pengguna terbanyak adalah Whatsapp, Google Classroom, Youtube sebanyak 5 orang. Diikuti pengguna Whatsapp, Facebook, Youtube sebanyak 4 orang. Kemudian yang hanya 2 penggunanya adalah kombinasi Google Classroom, Edmodo, Cisco Webex. Selain itu, penggunanya sebanyak 1 orang.

Hal yang menarik dari penelitian ini, meskipun mereka adalah guru PAUD dimana kegiatan pembelajaran tidak serumit tingkatan di atasnya, IPD bisa berkembang sampai dengan mengkombinasikan APD sebanyak 4 jenis, 5 jenis, bahkan 6 jenis. Untuk variasi keempat, 4 jenis APD yang dikombinasikan terbagi menjadi 2 kelompok ini yaitu 1) kombinasi Whatsapp, Youtube, Gmeet dan zoom, dan 2) kombinasi Whatsapp, Youtube, Gmeet dan zoom. Keduanya tercatat dengan masing-masing 1 pengguna. Berbeda untuk variasi kelima dimana penggunanya lebih banyak daripada variasi keempat, terdapat tiga kelompok kombinasi yang terbentuk dengan jumlah pengguna sebanyak 1 orang, diantaranya 1) Whatsapp, Google Classroom, Cisco Webex, Youtube, dan Telegram, 2) Whatsapp, Google Classroom, Google for Education, Cisco Webex, dan Youtube, dan 3) Whatsapp, Google Classroom, Zenius, Youtube, dan Telegram. Sedangkan, variasi keenam menjadi paling kecil jumlah penggunanya, yaitu 1 orang. Kombinasi APD yang digunakan adalah Whatsapp, Google Classroom, Facebook, Youtube, Google meet dan zoom.

\section{Dampak Pemanfaatan Aplikasi Pembelajaran Daring}

Untuk melihat dampak pemanfaatan aplikasi pembelajaran daring, terdapat empat hal yang ditinjau dalam penelitian ini yaitu, pengalaman tenaga pendidik PAUD di Sulawesi Selatan, penggunaan APD dalam hal kemudahan dan manfaat, penggunaan APD terhadap tumbuh kembang kognitif, sikap, dan psikomotorik, dan penggunaan APD terhadap dukungan kemampuan kognitif, perkembangan sikap, dan perkembangan psikomotorik.

\section{Pengalaman tenaga pendidik PAUD di Sulawesi Selatan}

Untuk bagian ini, para responden diminta untuk memberikan informasi tentang pengalaman yang mereka miliki tentang penggunaan aplikasi pembelajaran daring. Informasi yang diperoleh disajikan dalam bentuk gambar diagram di bawah ini.

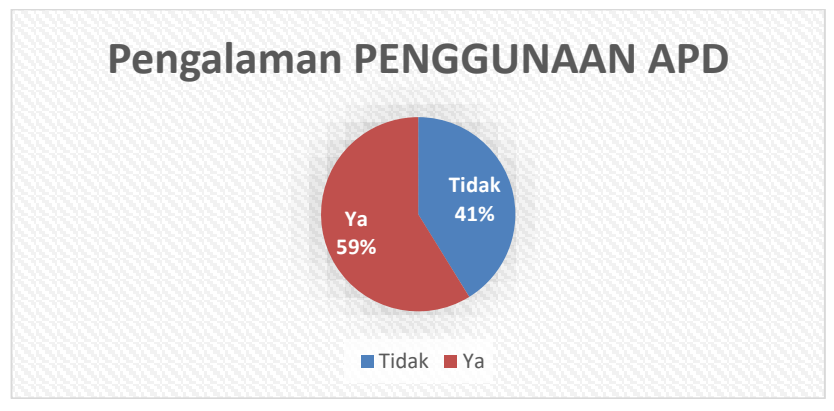

Gambar 2. Pengalaman Penggunaan APD Tenaga Pendidik PAUD Sul-Sel 
Untuk melihat dampak penggunaan APD dalam kegiatan pembelajaran yang dilakukan oleh pendidik PAUD. Pertama yang dilihat seperti tampak pada gambar 2 di atas, informasi tersebut menunjukkan seberapa besar proporsi responden yang berpengalaman dalam menggunakan APD dan sebaliknya. Proporsi responden yang berpengalaman sebesar $59 \%$, sedangkan yang tidak berpengalaman sebesar 41\%. Dengan kata lain, lebih dari 200 orang menyampaikan informasi bahwa mereka memiliki pengetahuan dalam menggunakan aplikasi tersebut untuk kegiatan pembelajaran. Namun, tidak sedikit juga yang tidak memiliki pengalaman menggunakan APD, tercatat kurang dari 150 orang. Pentingnya pengalaman merupakan bagian dari keinginan pengguna untuk bertransformasi dalam menerapkan inovasi pembelajaran (Zhang, 2010). Bahkan untuk dapat mendukung lingkungan pembelajaran yang efektif (Mulbar \& Nasrullah, 2016; Nasrullah; Baharman, 2016), aspek populer mendorong pengguna untuk mengintegrasikan dengan aktivitas yang dilakukan. Seperti tenaga pendidik di institusi dimana pesan teks digunakan sebagai media pengajaran dan pembelajaran karena mereka terbiasa dengan media yang populer (Lauricella \& Kay, 2013). Dengan kata lain, APD yang digunakan di dalam kegiatan pembelajaran merupakan aplikasi biasa digunakan oleh pendidik dan populer bagi sebagian besar orang di wilayah tersebut. Semakin bepengalaman, kemudian diadaptasi dan dikembangkan sebagai media pembelajaran akan semakin banyak manfaat untuk pembelajaran diperoleh.

\section{Respon Penggunaan APD dalam hal kemudahan dan manfaat}

Berkaitan dengan data pengalaman pendidik PAUD, seperti apa tanggapan mereka tentang kemudahan dan manfaat penggunaan APD tersebut. Data yang diperoleh disajikan ke dalam gambar 3

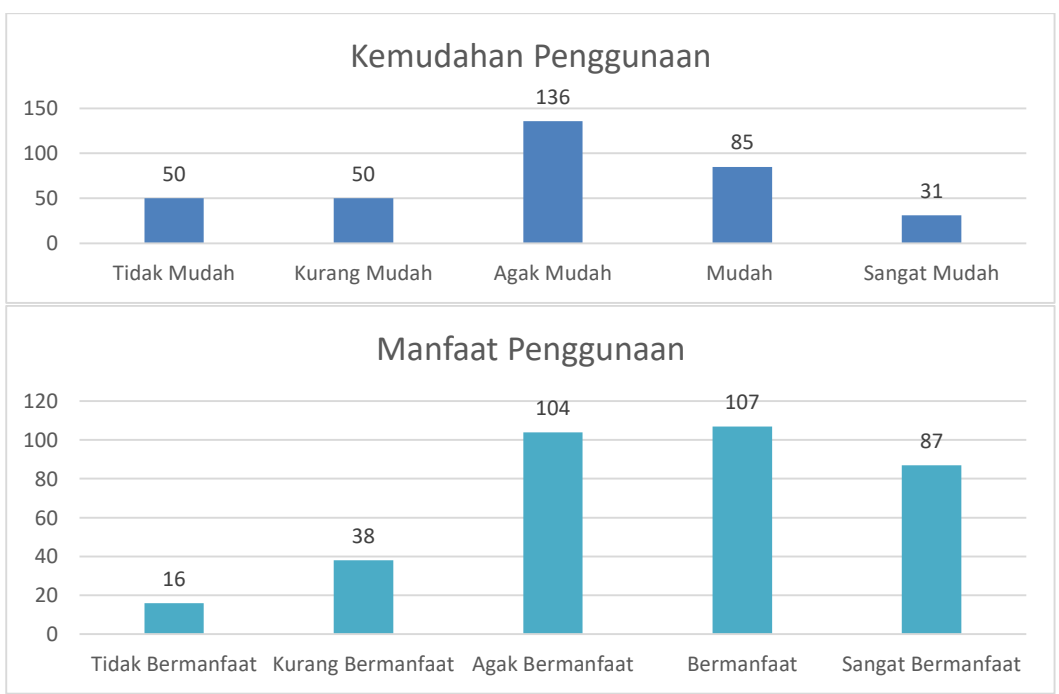

Gambar 3. Respon Penggunaan APD dalam hal kemudahan dan manfaat

Untuk gambar 3 ini, terdapat 2 diagram yang masing-masing menyajikan informasi tentang kemudahan penggunaan APD dan manfaat penggunaan APD. Dari kedua diagram tersebut, masing-masing memberikan kategori respon yang berbeda-beda. Untuk diagram tentang kemudahan penggunaan, respon dimulai dari tidak mudah sampai dengan sangat mudah. Meskipun diagram ini menunjukkan tren yang menurun dimana dimulai pada angka 
frekuensi 50 (respon tidak mudah dan respon kurang mudah) dan berada di atas angka frekuensi 25 untuk respon sangat mudah, namun terjadi kenaikan signifikan untuk angka frekuensi respon agak mudah, di atas 125. Sayangnya terjadi penurunan untuk angka frekuensi respon mudah, di atas 75. Secara keseluruhan, jumlah responden yang menanggapi positif kemudahan penggunaan APD lebih besar dibandingkan yang sebaliknya. Tidak sepenuhnya responden memberikan pendapat positif untuk aspek kemudahan sejalan dengan pendapat Utami \& Cahyono (2020) bahwa penggunaan APD memerlukan keterlibatan aktif seluruh pihak dimulai dari inisiatif, kebiasaan, peningkatan kemampuan teknologi, dan kemauan untuk evaluasi diri.

Selanjutnya diagram manfaat penggunaan APD, tren diagram menunjukkan respon positif. Meskipun terjadi penurunan angka frekuensi respon sangat bermanfaat, di atas 80 , angka frekuensi di dalam diagram ini dimulai dengan di bawah 20 respon kalau APD tidak bermanfaat dan di bawah 40 untuk respon APD kurang bermanfaat. Setelah itu, terjadi lonjakan respon yang signifikan untuk kategori agak bermanfaat hingga kategori bermanfaat, keduanya di atas angka 100. Secara keseluruhan, jumlah responden yang menanggapi positif manfaat penggunaan APD lebih besar dibandingkan yang bertentangan. Mereka yang berpendapat positif dalam hal ini menunjukkan bahwa peran teknologi telah berjalan sesuai yang dikehendaki oleh pengguna yaitu membantu proses belajar mengajar dengan baik (Pakpahan \& Fitriani, 2020)

Membahas apa yang dikemukakan oleh Harahap et al. (2021) bahwa penguasaan aplikasi menjadi masalah besar untuk pembelajaran yang dilaksanakan bagi peserta didik usia dini. Jika penguasaan tersebut dipengaruhi oleh pengalaman mereka menggunakan. Apa yang diperoleh di dalam penelitian ini, tidak semua yang tidak berpengalaman mengalami kesulitan dalam menerapkan APD untuk melaksanakan kegiatan pembelajaran. Begitu juga, penilaian mereka tentang nilai manfaat dari APD yang dikembangkan untuk mendukung aktivitas pengajaran mereka. Tidak semua yang tidak berpengalaman menilai APD tidak bermanfaat untuk kegiatan pembelajaran.

\section{Respon Penggunaan APD terhadap tumbuh kembang kognitif, sikap, dan psikomotorik}

Untuk respon penggunaan APD terhadap tumbuh kembang terbagi menjadi 3 bagian yaitu aspek APD terhadap Tumbuh Kembang Kognitif (APDTKK), APD terhadap Tumbuh Kembang Sikap (APDTKS), dan APD terhadap Tumbuh Kembang Psikomotorik (APDTKP). Untuk itu, terdapat 3 diagram balok untuk setiap kategori jawaban yang digunakan untuk menyajikan respon dalam gambar 4 .

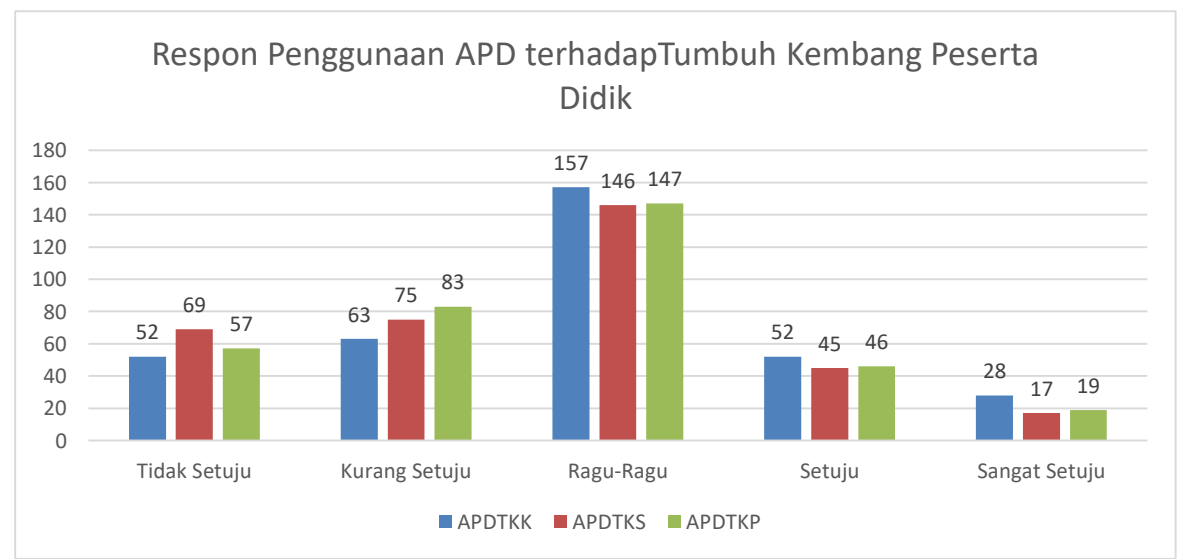

Gambar 4. Respon Penggunaan APD terhadap tumbuh kembang kognitif, sikap, dan psikomotorik 
Perlu dipahami bahwa gambar 4 di atas, kategori respon yang digunakan dimulai dari tidak setuju sampai dengan sangat setuju. Berdasarkan informasi yang digambarkan dalam diagram tersebut, ketiga diagram menunjukkan tren yang seragam, terjadi penurunan. Dengan kata lain, secara umum penggunaan APD tidak dianggap mendukung tumbuh kembang peserta didik baik kognitif, sikap, maupun psikomotorik. Hal ini sejalan dengan yang dikemukakan oleh Wulandari \& Purwanta (2020) dimana perkembangan anak selama pembelajaran daring tidak menunjukkan kemajuan pada beberapa aspek, sebaliknya terjadi penurunan. Meskipun hal ini perlu dikaji lebih lanjut pada aspek apa saja yang mengalami degradasi dalam kesempatan penelitian selanjutnya.

Respon Penggunaan APD terhadap dukungan kemampuan kognitif, perkembangan sikap, dan perkembangan psikomotorik

Untuk respon penggunaan APD terhadap dukungan kemampuan terbagi menjadi 3 bagian yaitu kemampuan kognitif, perkembangan sikap, dan perkembangan psikomotorik. Untuk itu, terdapat 3 diagram yang digunakan untuk menyajikan ketiga respon tersebut seperti yang ditampilkan dalam gambar 5 .

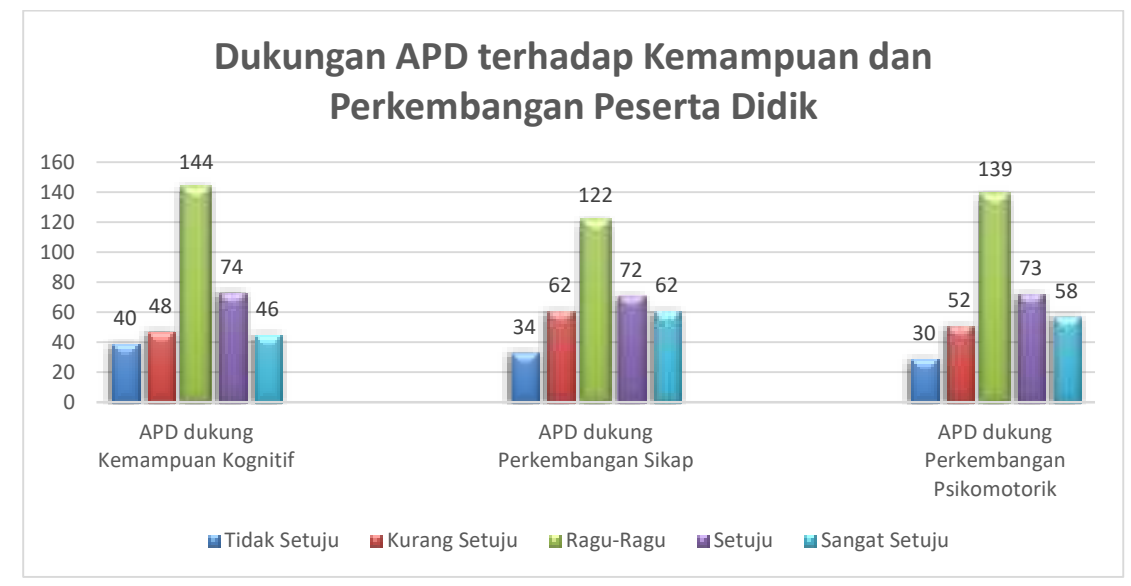

Gambar 5. Respon Penggunaan APD terhadap dukungan kemampuan kognitif, perkembangan sikap, dan perkembangan psikomotorik

Seperti yang terlihat dalam gambar 5 di atas terdapat 3 kelompok masing-masing, yaitu, 1) diagram APD dukung kemampuan kognitif (kiri), 2) diagram APD dukung perkembangan sikap (tengah), dan 3) diagram APD dukung perkembangan psikomotorik (kanan).

Kategori respon yang digunakan dimulai dari tidak setuju sampai dengan sangat setuju. Berdasarkan informasi yang digambarkan dalam diagram tersebut, ketiga diagram menunjukkan tren yang seragam, terjadi kenaikan. Dengan kata lain, secara umum penggunaan APD dianggap mendukung kemampuan kognitif, perkembangan sikap, dan perkembangan psikomotorik. Meskipun hal ini tidak berkaitan langsung dengan APD, dengan adanya keterlibatan orang tua mendampingi anak mereka untuk belajar bersama melalui APD tersebut menggiring intensitas komunikasi antara orang tua dan anak, terlibat aktif dalam kegiatan belajar bersama anak, dan menjadi pengarah yang baik bagi anak (Kurniati et al., 2020). Pada dasarnya, APD hanyalah sebuah alat atau teknologi yang membutuhkan sentuhan penggunanya sebab rancangan awalnya digunakan untuk 
mendukung terbentuknya kemampuan dan mendorong perkembangan subjeknya (Novita \& Herman, 2021). Untuk itu, para pendidik anak usia dini memberikan gambaran kesiapan berbeda-beda dan menyajikan kompleksitas metode pembelajaran yang tidak sama juga. Hal ini merupakan suatu bentuk adaptasi teknologi dan informasi yang diharapkan tidak hanya berlangsung selama pandemi, termasuk juga setelah pandemi (Rohmanu et al., 2020). Kemudian, variasi daring dan luring atau masih tetap menerapkan metode pembelajaran luring juga memberikan informasi para pendidik masih berharap pembelajaran tatap muka dilaksanakan. Karena itu, hal ini menarik untuk dieksplorasi lebih jauh tentang praktik baik seperti apa yang mereka lakukan. Jika terkendala oleh waktu, tempat, dan sumber daya manusia, maka pembelajaran daring dapat menjadi solusi (Nasrullah et al., 2021), sebaliknya jika menginginkan pertemuan pembelajaran yang berkualitas dan keleluasaan untuk berinteraksi satu sama lain maka yang diharapkan dengan pembelajaran secara tatap muka (Pratama \& Mulyati, 2020).

Adanya perbedaan kecenderungan pendapat di kalangan pendidik PAUD terkait dukungan APD terhadap tumbuh kembang anak dan dukungan APD terhadap peningkatan kemampuan dan perkembangan anak memerlukan tindakan atau strategi yang jitu untuk saling berbagai pengetahuan dan praktik baik terkait pembelajaran melibatkan APD. Harapannya para pendidik menyediakan alternatif untuk mengatasi hal tersebut selain juga menempatkan orang tua terlibat berpartisipasi aktif mengamati dan mendukung pembelajaran daring di rumah (Maryani, 2020).

\section{SIMPULAN}

Selama pembelajaran di masa pandemi Covid-19, tenaga pendidik PAUD memadukan berbagai APD menjadi 30 variasi aplikasi untuk pembelajaran daring dan 4 variasi pembelajaran hybrid. Praktik baik ini merupakan bentuk adaptasi teknologi dan informasi yang ditujukan untuk pembelajaran anak usia dini. Meskipun tidak semuanya memiliki pengalaman penggunaan, setidaknya pengalaman merupakan pengetahuan awal bagi pengguna tentang APD sedemikian sehingga berdampak pada kemudahan penggunaan. Tanpa pengalaman juga tidak berarti menjadi kendala bagi mereka merasakan manfaat penggunaan APD tersebut. Dari proses pemanfaatan dan adaptasi APD, responden cenderung tidak mengutamakan APD mendukung tumbuh kembang peserta didik baik kognitif, sikap, maupun psikomotorik. Namun, responden cenderung mendukung APD dapat membantu peserta didik untuk meningkatkan kemampuan kognitif, perkembangan sikap, dan perkembangan psikomotorik.

\section{UCAPAN TERIMA KASIH}

Kami mengucapkan terima kasih kepada kelompok Guru Pendidikan Anak Usia Dini wilayah Sulawesi Selatan atas dukungan dan bantuannya dalam pengumpulan data penelitian ini.

\section{DAFTAR PUSTAKA}

Abidah, A., Hidaayatullaah, H. N., Simamora, R. M., Fehabutar, D., \& Mutakinati, L. (2020). The Impact of Covid-19 to Indonesian Education and Its Relation to the Philosophy of "Merdeka Belajar." Studies in Philosophy of Science and Education, 1(1), 38-49. https://doi.org/10.46627/sipose.v1i1.9

Ammas, S. (2021). Jurnal Sipatokkong BPSDM Sulawesi Selatan Pembelajaran Daring dalam Perspektif Merdeka Belajar. 2(1), 35-46.

Andrianto Pangondian, R., Insap Santosa, P., \& Nugroho, E. (2019). Faktor - Faktor Yang Mempengaruhi Kesuksesan Pembelajaran Daring Dalam Revolusi Industri 4.0. Sainteks 2019, 56-60. https:// seminar-id.com/semnas-sainteks2019.html 
Aubrey, C., \& Dahl, S. (2014). The confidence and competence in information and communication technologies of practitioners, parents and young children in the Early Years Foundation Stage. Early Years, 34(1), 94-108. https:// doi.org/10.1080/09575146.2013.792789

Cahyati, N., \& Kusumah, R. (2020). Peran Orang Tua Dalam Menerapkan Pembelajaran Di Rumah Saat Pandemi Covid 19. Jurnal Golden Age, 4(01), 4-6. https://doi.org/10.29408/jga.v4i01.2203

Dong, C., Cao, S., \& Li, H. (2020). Young children's online learning during COVID-19 pandemic: Chinese parents' beliefs and attitudes. Children and Youth Services Review, 118(September), 105440. https:// doi.org/10.1016/j.childyouth.2020.105440

Enriquez, M. A. S. (2014). Students ' Perceptions on the Effectiveness of the Use of Edmodo as a Supplementary Tool for Learning. DLSU Research Congress, 6-11. https://doi.org/10.1017/CBO9781107415324.004

Fadlilah, A. N. (2020). Strategi Menghidupkan Motivasi Belajar Anak Usia Dini Selama Pandemi COVID-19 melalui Publikasi. Jurnal Obsesi : Jurnal Pendidikan Anak Usia Dini, 5(1), 373. https:// doi.org/10.31004/obsesi.v5i1.548

Fenech, M. (2007). The impact of regulation on quality in long day care in New South Wales: Teachers' perceptions and a critical analysis. Macquarie University.

Gheytasi, M., Azizifar, A., \& Gowhary, H. (2015). The Effect of Smartphone on the Reading Comprehension Proficiency of Iranian EFL Learners. Procedia - Social and Behavioral Sciences, 199(August 2015), 225-230. https:/ / doi.org/10.1016/i.sbspro.2015.07.510

Hanifah Salsabila, U., Irna Sari, L., Haibati Lathif, K., Puji Lestari, A., \& Ayuning, A. (2020) Peran Teknologi Dalam Pembelajaran Di Masa Pandemi Covid-19. Al-Mutharahah: Jurnal Penelitian Dan Kajian Sosial Keagamaan, 17(2), 188-198. https://doi.org/10.46781/al-mutharahah.v17i2.138

Harahap, S. A., Dimyati, D., \& Purwanta, E. (2021). Problematika Pembelajaran Daring dan Luring Anak Usia Dini bagi Guru dan Orang tua di Masa Pandemi Covid 19. Jurnal Obsesi : Jurnal Pendidikan Anak Usia Dini, 5(2), 1825-1836. https://doi.org/10.31004/obsesi.v5i2.1013

Jooston, T. (University of W.-M., Lee-McCarty, K. (Online L. C., Harness, Li. (Alverno C., \& Paulus, R. (National R. C. for D. E. and T. A. (2020). Digital Learning Innovation Trends. 33.

Kemdikbud RI. (2020). Kementerian Pendidikan dan Kebudayaan. Http://Kemdikbud.Go.Id/, Mei. http://kemdikbud.go.id/main/?lang=id

Kurniati, E., Nur Alfaeni, D. K., \& Andriani, F. (2020). Analisis Peran Orang Tua dalam Mendampingi Anak di Masa Pandemi Covid-19. Jurnal Obsesi : Jurnal Pendidikan Anak Usia Dini, 5(1), 241. https://doi.org/10.31004/obsesi.v5i1.541

Lauricella, S., \& Kay, R. (2013). Exploring the use of text and instant messaging in higher education classrooms. Research in Learning Technology, 21(1063519), 1-17. https://doi.org/10.3402/rlt.v21i0.19061

Lindawati, Y. I. dan C. A. R. (2019). Adaptasi Guru Dalam Implementasi Pembelajaran Daring Di Era Pandemi Covid-19. Prosiding Seminar Nasional Pendidikan FKIP, 3(2252), 58 66.

http:/ / www.tjyybjb.ac.cn/CN/article/downloadArticleFile.do?attachType=PDF\&id $=9987$

Maryani, K. (2020). Penilaian dan Pelaporan Perkembangan Anak Saat Pembelajaran di Rumah di Masa Pendemi Covid-19. Murhum : Jurnal Pendidikan Anak Usia Dini, 1(2), 41-52. https:// doi.org/10.37985/murhum.v1i1.4

Mondal, H., Mondal, S., Ghosal, T., \& Mondal, S. (2019). Using Google Forms for Medical Survey: A Technical Note. International Journal of Clinical and Experimental Physiology, 5(4), 216-218. https:// doi.org/10.5530/ijcep.2018.5.4.26 
Inovasi Pembelajaran Daring dan Dampak Bagi PAUD Selama Pandemi Covid-19

DOI: 10.31004/obsesi.v6i2.1411

Mulbar, U., \& Nasrullah. (2016). Applying SARAC Approach and The Effect in Learning Mathematics For Students Grade VIII. October, 325-331.

Nasrullah; Baharman. (2016). Pengaruh SMP Virtual terhadap Kemampuan Penalaran dan Komunikasi Siswa dalam Pembelajaran Matematika. 662-666.

Nasrullah; Baharman. (2017). Pengaruh SMP Virtual terhadap Kemampuan Penalaran dan Komunikasi Siswa dalam Pembelajaran Matematika. Proceedings of National Seminar: Research and Community Service Institute Universitas Negeri Makassar, 662-666. https://ojs.unm.ac.id/semnaslemlit/article/view/4118

Nasrullah, Suradi, \& Hamda. (2021). Study of Clarification Android Based Worksheet of Topic Cartesian Coordinate at Level Junior Secondary. Journal of Physics: Conference Series, 1752. https://doi.org/10.1088/1742-6596/1752/1/012079

Novita, R., \& Herman, T. (2021). Digital technology in learning mathematical literacy, can it helpful? Journal of Physics: Conference Series, 1776(1). https:// doi.org/10.1088/17426596/1776/1/012027

Pakpahan, R., \& Fitriani, Y. (2020). Analisa Pemafaatan Teknologi Informasi Dalam Pemeblajaran Jarak Jauh Di Tengah Pandemi Virus Corona Covid-19. JISAMAR (Journal of Information System, Applied, Management, Accounting and Researh), 4(2), 30-36.

Phajane, M. H. (2014). Exploring the roles and responsibilities of early childhood teachers. Mediterranean Journal of Social Sciences, 5(10 SPEC. ISSUE), 420-424. https://doi.org/10.5901/mjss.2014.v5n10p420

Pratama, R. E., \& Mulyati, S. (2020). Pembelajaran Daring dan Luring pada Masa Pandemi Covid-19. Gagasan Pendidikan Indonesia, 49. https://doi.org/10.30870/gpi.v1i2.9405

Ratu, D., Uswatun, A., \& Pramudibyanto, H. (2020). Pendidikan Dalam Masa Pandemi Covid$19 . \quad$ Jurnal Sinestesia, $10(1), \quad 41-48$. https:// sinestesia.pustaka.my.id/journal/article/view/44

Ridwan, \& Nasrullah. (2015). Kontribusi Pendekatan 2pm Terhadap Kemajuan Kemampuan Menyelesaikan Masalah Matematika Siswa Smpn 3 Tanete Riaja. Optimalisasi HasilHasil Penelitian Dalam Menunjang Pembangunan Berkelanjutan, 903-911.

Rohmanu, A., Muafiah, E., Rahman Hakim, A., \& W Damayanti, V. V. (2020). Kesiapan, Kompleksitas Dan Harapan Pembelajaran Jarak Jauh: Perspektif Mahasiswa Iain Ponorogo. Al-Tadzkiyyah: Jurnal Pendidikan Islam, 11(2), 221-241. http://103.88.229.8/index.php/tadzkiyyah/article/view/7019

So, S. (2016). Mobile instant messaging support for teaching and learning in higher education.

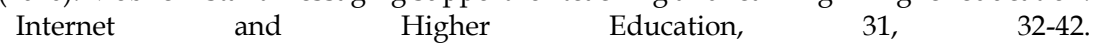
https://doi.org/10.1016/j.iheduc.2016.06.001

Suhendro, E. (2020). Strategi Pembelajaran Pendidikan Anak Usia Dini di. Golden Age: Jurnal Ilmiah Tumbuh Kembang Anak Usia Dini, 5(September), 133-140. https://doi.org/10.14421/iga.2020.53-05

Susanti, D. I., \& Prameswari, J. Y. (2020). Adaptasi Blended Learning di Masa Pandemi COVID-19 untuk Pembelajaran Bahasa Inggris di Sekolah Dasar. Lingua Susastra, 1(2), 50-61. https:// doi.org/10.24036/ls.v1i2.8

Utami, Y. P., \& Cahyono, D. A. D. (2020). Study At Home: Analisis Kesulitan Belajar Matematika Pada Proses Pembelajaran Daring. Jurnal Ilmiah Matematika Realistik, 1(1), 20-26. https://doi.org/10.33365/ji-mr.v1i1.252

Wulandari, H., \& Purwanta, E. (2020). Pencapaian Perkembangan Anak Usia Dini di Taman Kanak-kanak selama Pembelajaran Daring di Masa Pandemi Covid-19. Jurnal Obsesi : Jurnal Pendidikan Anak Usia Dini, 5(1), 452. https:/ / doi.org/10.31004/obsesi.v5i1.626

Zhang, J. (2010). Technology-supported learning innovation in cultural contexts. Educational Technology Research and Development, 58(2), 229-243. https://doi.org/10.1007/s11423-009-9137-6 